\title{
Antioxidant and Antityrosinase Activities of Ethanolic Pachyrhizuserosus Peel and Tuber Extract
}

\author{
Irma Dolsyeria Siregar, ${ }^{1}$ Hanna Sari W. Kusuma, ${ }^{2}$ Wahyu Widowati, ${ }^{3}$ Hans Hotma Marpaung, ${ }^{4}$ \\ Sahna Ferdinand, ${ }^{4}$ Edy Fachrial, ${ }^{4}$ I Nyoman Ehrich Lister ${ }^{4}$ \\ ${ }^{1}$ Master in Biomedical Science, Faculty of Medicine Universitas Prima Indonesia, Medan, Indonesia, \\ ${ }^{2}$ Biomolecular and Biomedical Research Center, Aretha Medika Utama, Bandung, Indonesia, \\ ${ }^{3}$ Faculty of Medicine Maranatha Christian University, Bandung, Indonesia, ${ }^{4}$ Faculty of Medicine Universitas \\ Prima Indonesia, Medan, Indonesia
}

\begin{abstract}
Aging process is a physiological process in living organisms caused by, among others, free radicals. One of the free-radical-related aging problems is skin hyperpigmentation (excessive melanin) due to increasing tyrosinase enzyme activities. Natural compounds are widely used as antioxidant and antiaging agents. Bengkuang (Pachyrhizuserosus) is known as a source of various active compounds which can be used against free radicals to reduce the risk of skin aging through tyrosinase enzyme inhibition. This study was performed in September 2018 in Aretha Medika Utama, Biomolecular and Biomedical Research Center, Bandung, Indonesia to examine the antioxidant and antityrosinase properties of Pachyrhizuserosus peel extract (PPE) and Pachyrhizuserosus tuber extract (PTE).The extraction of PPE and PTE was performed using 70\% ethanol by maceration method, followed by phytochemical analysis using modified Farnsworth method. Antioxidant activities were measured through 2,2-Diphenyl-1-picrylhydrazil (DPPH) scavenging activities while antiaging assay were conducted through the tyrosinase activity inhibition. In this study, PPE contained saponin, tannin, triterpenoid, and terpenoid while the PTE showed the presence of flavonoid, saponin, phenol, tannin, and alkaloid in phytochemical analysis. In the antioxidant assay, PPE presented a higher DPPH scavenging activities (IC50 $=84.09 \mu \mathrm{g} / \mathrm{mL}$ ) when compared to PTE (IC50 $=98.30 \mu \mathrm{g} / \mathrm{mL})(\mathrm{p}<0.05)$. In antiaging assay, PPE showed a higher tyrosinase inhibitory activities when compared to PTE with $=97.05 \mu \mathrm{g} / \mathrm{mL}$ and $194.51 \mu \mathrm{g} / \mathrm{mL}$,respectively. It can be concluded that PPE has antioxidant and antiaging activities effective for preventing skin aging.
\end{abstract}

Key words: Aging, antioxidant, hyperpigmentation, Pachyrhizuserosus, tyrosinase

\section{Aktivitas Antioksidan dan Antitirosinase Ekstrak Etanol Kulit dan Daging Pachyrhizuserosus}

\begin{abstract}
Abstrak
Proses penuaan merupakan suatu proses fisiologis yang terjadi pada makhluk hidup yang dapat disebabkan oleh radikal bebas. Hiperpigmentasi kulitmerupakan salah satu masalah penuaan yang disebabkan oleh radikal bebas melalui peningkatan aktivitas enzim tirosinase. Bengkuang (Pachyrhizus erosus) diketahui mengandung berbagai senyawa aktif yang dapat menangkal radikal bebas serta mengurangi risiko penuaan kulit. Penelitian dilaksanakan pada September 2018 di Aretha Medika Utama, Biomolecular and Biomedical Research Center, Bandung, Indonesia untuk menguji kemampuan aktivitas antioksidan dan antitirosinase pada ekstrak etanol kulit bengkuang (EEKB) dan ekstrak etanol daging bengkuang (EEDB). Pembuatan ekstrak kulit dan daging bengkuang dilakukan dengan cara mengekstraksi bahan dengan etanol 70\% menggunakan metode maserasi, kemudian dilanjutkan dengan analisis fitokimia ekstrak dengan modifikasi metode Farnsworth. Aktivitas antioksidan diuji dengan mengukur pemerangkapan 2,2-Diphenyl-1-picrylhydrazil (DPPH) sedangkan antiaging diuji dengan mengukur aktivitas penghambatan tirosinase. Pada uji fitokimia menunjukkan EEKB memiliki kandungan senyawa saponin, tanin, triterpenoid dan terpenoid, sedangkan EEDB menunjukkan kandungan senyawa flavonoid, saponin, fenol, tanin, dan alkaloid. Pada uji antioksidan, EEKB memiliki aktivitas tertinggi pada pemerangkapan DPPH $\left(\mathrm{IC}_{50}=84.09 \mu \mathrm{g} /\right.$ $\mathrm{mL}$ ) dibanding dengan EEDB $\left(\mathrm{IC}_{50}=98.30 \mu \mathrm{g} / \mathrm{mL}\right)(p \leq 0.05)$. Pada pengujian antiaging, EEKB memiliki nilai yang lebih tinggi pada aktivitas penghambatan tirosinase dibandingkan dengan EEDB ( $\mathrm{IC}_{50}=97.05 \mu \mathrm{g} / \mathrm{mL} ; 194.51 \mu \mathrm{g} /$ $\mathrm{mL}(p \leq 0.05)$. Simpulan, EEKB memiliki aktivitas antioksidan dan antiaging sehingga efektif dalam mencegah penuaan kulit.
\end{abstract}

Kata kunci: Antioksidan, Pachyrhizuserosus, penuaan, tirosinase

Corresponding Author: I Nyoman Enrich Lister, Faculty of Medicine, Universitas Prima Indonesia, Medan, Jalan Belanga No.1, Sei Putih Tengah, Medan Petisah, North Sumatera, 20118, Indonesia, Email: yysunpri@gmail.com 


\section{Introduction}

Tyrosinase enzyme has to play a major role in melanin synthesis being responsible as a dark pigment in the skin. ${ }^{1}$ Overactivity of tyrosinase enzyme also leads to overproduction of melanin leading to hyperpigmentation of the skin. ${ }^{1}$ Melanin is the pigment in the human and animal skin that is synthesized by tyrosinase from L-tyrosine to L-DOPA, following the oxidation of L-DOPA to L-DOPA quinone. ${ }^{2}$

Ultraviolet radiation, inflammatory mediators and hormones can upregulate melanogenesis inducing skin hyperpigmentation. ${ }^{3}$ Free radicals such as UV radiation have played roles in tyrosinase activation of human skin through melanocyte proliferation. Thus, antioxidant as reactive oxygen species (ROS) inhibitors may decrease hyperpigmentation and that can be used as whitening products. ${ }^{3}$

Many cosmetics or skin lightening agents contain tyrosinase inhibitors and they have been sold commercially. Some of them have been available as chemical and fungal derived skin-lightening agents having chronic, cytotoxic, and mutagenic effects in humans. ${ }^{5}$ Inhibition of melanogenesis in cells without side effects may be a good solution using inhibitor-target tyrosinase, as tyrosinase is produced by melanocytes. This inhibitor-target tyrosinase can be used to treat skin diseases caused by the accumulation of melanin such as melasma, solar lentigo, and freckles. ${ }^{4,5}$ Skin hyperpigmentation can trigger diseases of the skin so that the natural sources of tyrosinase inhibitors were needed. ${ }^{1}$

Pachyrizuserosus L. (Fabaceae), commonly known as bengkuang grows in many areas of tropical and sub-tropical regions, especially in Indonesia. ${ }^{6} P$. erosustuber has brown-skinned that has been used as whitening agents through inhibition of melanogenesis and usually used in cosmetic products. ${ }^{2}$ P. erosus has some properties such as anti-inflammatory, antibacterial, antioxidant, anti-tyrosinase activities. ${ }^{7}$

The tuber of bengkuang has tyrosinase and protein expression inhibitory activity so it canbe used as skin whitening products. ${ }^{2}$ In the present study, antioxidant activity of $P$. erosus peel (PPE) and tuber extracts (PTE) through DPPH scavenging activity were evaluated as well as tyrosinase inhibitory activity (antiaging).

\section{Methods}

Bengkuang ( $P$. erosus) plants were collected from Ciampea-Bogor, West Java, Indonesia. The plants were identified by herbarium staff, Department of Botanical, Indonesian Institute of Sciences, Bogor, West Java, Indonesia. This study was conducted in September 2018 in Aretha Medika Utama, Biomolecular and Biomedical Research Center, Bandung, Indonesia. Extraction of P. erosus using maceration by Widowati et al. ${ }^{9}$ method. The tuber $(100 \mathrm{~g})$ and peel $(150 \mathrm{~g})$ of $P$. erosus were mashed, and then using $1300 \mathrm{~mL}$ distilled ethanol $70 \%$ for extraction each sample. Then, the ethanol filtrate was filtered and wastes were re-macerated until colorless filtrate every $24 \mathrm{~h}$. Maceration were concentrated using $50^{\circ} \mathrm{C}$ evaporator to obtain the extract. The tuber $P$. erosusextracts $(31.05 \mathrm{~g})$ and peel $(28.77 \mathrm{~g}) P$. erosus extracts was stored at $-20^{\circ} \mathrm{C} .{ }^{9}$

Phytochemical screening assay was evaluated using a modified Farnsworth method. The ethanol extracts of peel and tuber were tested for the presence of flavonoids, saponins, phenols, tannins, steroids/triterpenoids, terpenoids, and alkaloids. The qualitative results were expressed as $(+)$ for the presence and $(-)$ for the absence of phytochemicals. ${ }^{9}$

Flavonoidsassay-PPE and PTE (10 mg) was dropped into a test tube and added Magnesium (Mg) [Merck EM105815, USA] and Hydrochloric acid ( $\mathrm{HCl}) 2 \mathrm{~N}$. The mixture sample was heated for 5 to $10 \mathrm{~min}$, then it was cooled down and filtered, and then added amyl alcohol. The formation of red or orange color shows the presence of flavonoids compound. ${ }^{9}$

Saponins assay - PPE and PTE $(10 \mathrm{mg})$ was added into the test tube with some water and boiled for $5 \mathrm{~min}$, shaken it vigorously. Saponins content was indicated by the persistence of froth on the surface. ${ }^{9}$

Test for phenols - PPE and PTE (10 mg) was placed on a dropping plate, then added $1 \% \mathrm{FeCl}_{3}$ [Merck 103943, USA] into the sample. If resulted color formation of green/red/purple/blue/black showed phenols compound. ${ }^{9}$

Tannins assay-PPE and PTE (10 mg) was added with $2 \mathrm{~mL}$ of $\mathrm{HCl} 2 \mathrm{~N}$ [Merck 1003171000 , USA] in the test tube, then heated on a water bath for $30 \mathrm{~min}$. Then, the mixture was cooled down and filtered, the filtrate was added with amyl alcohol [Merck 10979, USA]. The presence of tannins indicated of purple color formation. ${ }^{9}$

Steroids/triterpenoids-Ten milligram of PPE and PTE was placed on a dropping plate, and then soaked with acetate acid until the sample was covered. Then, after 10-15 min added one drop of absolute sulphate acid $\left(\mathrm{H}_{2} \mathrm{SO}_{4}\right)$ [Merck 109073, USA]. The color formation of green/ 
blue showed the presence of steroids while red or orange sediment indicated the presence of triterpenoids. ${ }^{9}$

Terpenoids assay- PPE and PTE (10 mg) were added into a dropping plate, then added vanillin and $\mathrm{H}_{2} \mathrm{SO}_{4}$ [Merck 109073, USA]. Formation purple color on the mixture indicated the presence of terpenoids. ${ }^{9}$

Alkaloids assay- Ten milligram amount of PPE and PTE was added into a test tube. Briefly, the sample was dropped $10 \%$ ammonia solution. Then, chloroform was added to the mixture, forming two layers of liquid and the bottom layer was collected to a new test tube. $\mathrm{HCl} 1 \mathrm{~N}$ was added to the liquid, forming two layers and the upper layer was taken and Draggendorf solution was added (1-2 drops). The color formation of yellow show the presence of alkaloid content. ${ }^{9}$

Samples $(50 \mu \mathrm{L})$ was added to each well in a 96-well microplate. After that, $200 \mu \mathrm{L}$ of 2,2-Diphenyl-1-picrylhydrazil (DPPH) [Sigma Aldrich D9132, USA] solution $(0.077 \mathrm{mmol} / \mathrm{L}$ in methanol [Merck 1060092500, USA]) was added into each well, then the mixture incubated in the dark for $30 \mathrm{~min}$ at room temperature. The absorbance was measured using a microplate reader (Thermo Scientific, Multiskan ${ }^{\mathrm{TM}}$ GO Microplate Spectrophotometer, USA) at $517 \mathrm{~nm}$ wavelength. ${ }^{9}$ The median inhibitory concentration $\left(\mathrm{IC}_{50}\right)$ of the extract needed to inhibit $50 \%$ of the DPPH radicals were calculated.

The percentage of inhibition was calculated using the following equation:

\section{Scavenging $\%=(A c-A s) / A c \times 100$}

Note: Ac was negative control absorbance

As was sample absorbance is absorbance of a test sample

Tyrosinase inhibitory activity was measured spectrophotometrically based on Widowati et al. ${ }^{9}$ methods with some modifications. Ethanol extracts from tuber and peel of a P. erosus were evaluated for their inhibitory activity using L-3,4dihydroxyphenylalanine (L-DOPA) as substrate; $20 \mu \mathrm{L}$ sample with various concentration and $20 \mu \mathrm{L}$ tyrosinase enzyme from mushroom (125 $\mathrm{U} / \mathrm{ml}$ in potassium phosphate buffer)were prepared in 96 well-plate. Briefly, the sample was added potassium phosphate buffer $(140 \mu \mathrm{l}$, $20 \mathrm{mM}, \mathrm{pH}$ 6.8). Then, the mixture solution was incubated at room temperature for $15 \mathrm{~min}$. A twenty microlitres L-DOPA $(1.5 \mathrm{mM})$ was added, then incubated for $10 \mathrm{~min}$ at room temperature. Tyrosinase inhibitory activity was measured by quantifying the level of DOPA that was formed at
$470 \mathrm{~nm}$ wavelength.

$$
\text { Tyrosinase Inhibitory Activity (\%): } \frac{A-B}{A} \times 100
$$

Where A was control absorbance and B was sample absorbance. The concentration for $50 \%$ inhibition $\left(\mathrm{IC}_{50}\right)$ was determined. ${ }^{15}$

All data were expressed as mean \pm standard deviation of triplicate measurements and were subjected to statistical analysis using Analysis of variance (One Way ANOVA) followed by Tukey's HSD Post-hoc Test. Statistical analysis was performed using SPSS software (version 20.0). A value of $\mathrm{p} \leq 0.05$ was considered as significant of the data.

\section{Results}

Phytochemical analysis was to investigate the presence of phytochemicals in PPE and PTE using qualitative test. Based on Table 1. PTE had the presence of flavonoids, saponins, phenols, tannins, steroids, and alkaloids ( + ), while PPE has presence some compounds, saponins, tannins, triterpenoids, and terpenoids.

DPPH is a stable free radical because of the unpaired electron that becomes paired in the presence of hydrogen donors. ${ }^{9}$ The DPPH scavenging activity of PPE and PTE was performed in Figure 1 and Table 2. In Figure 1, DPPH activity was increased in a dose-dependent manner. In the highest concentration $(200 \mu \mathrm{g} /$ $\mathrm{mL}$ ), PPE had a higher activity compared to PTE $(67.69 \%$ and $67.03 \%$, respectively) $(\mathrm{p} \leq 0.05)$. This indicated that PPE had higher antioxidant activity. In Table 2 showed that PPE had a lower value $\left(\mathrm{IC}_{50}=84.09 \pm 4.87 \mu \mathrm{g} / \mathrm{mL}\right)$ compared to PTE value $\left(\mathrm{IC}_{50}=98.30 \pm 1.30 \mu \mathrm{g} / \mathrm{mL}\right)$. However, PPE had high DPPH scavenging activity among treatments.

\section{Table 1 Phytochemical analysis of PPE and} PTE

\begin{tabular}{lcc}
\hline Phytochemical Content & PPE & PTE \\
\hline Flavonoids & - & + \\
Saponins & + & + \\
Phenols & - & + \\
Tannins & + & + \\
Steroids/Triterpenoids & + & + \\
Terpenoids & + & - \\
Alkaloids & + & + \\
\hline
\end{tabular}

+: detected content, -: not detected 
Table 2 The $\mathrm{IC}_{50}$ Value DPPH Scavenging Activity of PPE and PTE

\begin{tabular}{ccccc}
\hline Sample & Linear Equation & $\mathbf{R}^{2}$ & $\mathbf{I C}_{\mathbf{5 0}}(\boldsymbol{\mu g} / \mathbf{m L})$ & $\begin{array}{c}\mathbf{I C}_{\mathbf{5 0}} \\
(\boldsymbol{\mu g} / \mathbf{m L})\end{array}$ \\
\hline \multirow{3}{*}{ PPE } & $\mathrm{y}=0.1627 \mathrm{x}+35.405$ & 0.97 & 89.70 & \\
& $\mathrm{y}=0.1582 \mathrm{x}+37.192$ & 0.96 & 80.96 & $84.09 \pm 4.87$ \\
\multirow{3}{*}{ PTE } & $\mathrm{y}=0.1654 \mathrm{x}+36.503$ & 0.96 & 81.60 & \\
& $\mathrm{y}=0.1677 \mathrm{x}+34.297$ & 0.92 & 93.64 & $98.30 \pm 1.30$ \\
\hline
\end{tabular}

*PPE $=$ P. erosus peel extract, $\mathrm{PTE}=P$. erosus tuber extract, $\mathrm{R} 2=$ coefficient of regression, IC50 $=$ The half maximal inhibitory concentration

Table 3 The IC ${ }_{50}$ Value Tyrosinase Inhibition Activity of PPE and PTE

\begin{tabular}{|c|c|c|c|c|}
\hline Sample & Linear Equation & $\mathbf{R}^{2}$ & $\mathrm{IC}_{50}(\mu \mathrm{g} / \mathrm{mL})$ & $\underset{(\mu \mathrm{g} / \mathrm{mL})}{\mathrm{IC}_{50}}$ \\
\hline \multirow{2}{*}{ PPE } & $y=0.3335 x+17.51$ & 0.95 & 96.99 & \multirow{3}{*}{$97.05 \pm 0.86$} \\
\hline & $y=0.3362 x+16.966$ & 0.96 & 98.26 & \\
\hline \multirow{4}{*}{ PTE } & $y=0.3296 x+17.495$ & 0.98 & 98.62 & \\
\hline & $y=0.2289 x+3.6363$ & 0.95 & 202.55 & \multirow{3}{*}{$194.51 \pm 7.63$} \\
\hline & $y=0.2527 x+2.6511$ & 0.98 & 187.37 & \\
\hline & $y=0.2447 x+2.6249$ & 0.98 & 193.60 & \\
\hline
\end{tabular}

*PPE $=$ P. erosus peel extract, $\mathrm{PTE}=$ P. erosus tuber extract, $\mathrm{R} 2=$ coefficient of regression, IC50= The half maximal inhibitory concentration

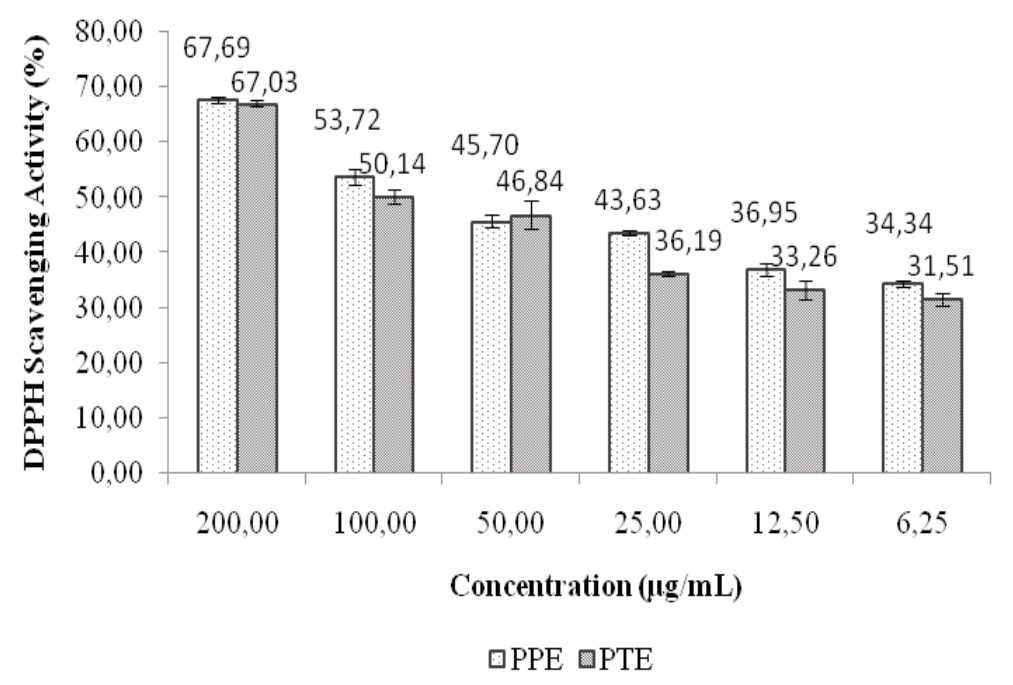

Figure 1 Effect Various Concentrations of PPE and PTE toward DPPH Scavenging Activity

*PPE $=$ P. erosus peel extract; $\mathrm{PTE}=P$. erosus tuber extract. Each value is expressed as the mean $\pm \mathrm{SD}$ of triplicate determinations. Statistical analysis was performed using a one-way ANOVA $(p \leq 0.05)$ 


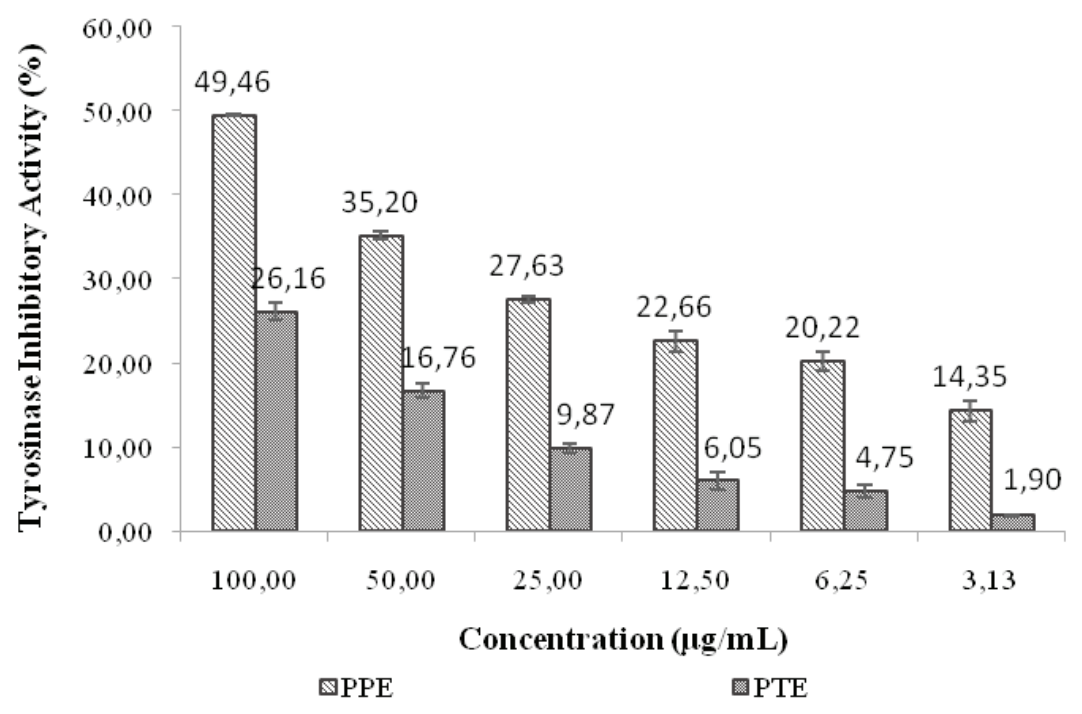

Figure 2 Effect Various Concentrations of PPE, PTE toward Tyrosinase Inhibitory Activity *Each value is expressed as the mean \pm SD of triplicate determinations. Statistical analysis was performed using a one-way ANOVA $(\mathrm{p} \leq 0.05)$

Tyrosinase inhibitory activity of PPE and PTE can be seen in Figure 2 and Table 3. Figure 2 showed that the tyrosinase activities of PPE and PTE were increased in a dose-dependent manner. PPE exhibited higher inhibition of tyrosinase $(49.46 \%)$ compared to PTE $(26.16 \%)$ at the concentration $100.00 \mu \mathrm{g} / \mathrm{mL}$ (Figure 2). The higher amount of PPE show it has a stronger inhibitory effect on tyrosinase ( $\mathrm{p} \leq 0.05)$.

PPE had the lower value $\left(\mathrm{IC}_{50}=84.09 \pm 4.87\right.$ $\mu \mathrm{g} / \mathrm{mL})$ compared to PTE value $\left(\mathrm{IC}_{50}=98.30 \pm 1.30\right.$ $\mu \mathrm{g} / \mathrm{mL})$. When $\mathrm{IC}_{50}$ values of the extracts were compared, PPE was found to be more effective, reaching the $\mathrm{IC}_{50}$ at a much lower concentration than PTE (Table 3).

\section{Discussion}

Pachyrizuserosusis a medicinal plant that has been reported to be a good source of antioxidant and antiaging. ${ }^{8}$ P. erosushad shown to inhibit skin pigmentation resulting from UV irradiation. ${ }^{2}$ $P$. erosus peel extracts could be suggested as new sources of antiaging agents besides using the tuber of $P$. erosus. In the present study, the phytochemical analysis had been done to identify some compounds in P. erosus peel and tuber extracts. PPE had presence compounds of saponins, tannins, triterpenoids, and terpenoids, while in PTE had flavonoids, saponins, phenols, tannins, steroids, and alkaloids. On another hand, P. erosus had saponin and alkaloid compounds, but not detected terpenoid, flavonoid and tannin. ${ }^{10}$ Saponins in $P$. erosus also can prevent skin damage from free radical as the result of absorption of ultra-violet rays..$^{11}$ Terpenoid has the ability in $\mathrm{OH}$ and SOD radical scavenging activity and it also can prevent aging. ${ }^{12}$ In another study reported that PTE had phytochemical compounds such as flavonoids, retinoids, and phenylfuranocoumarin. ${ }^{7}$ Flavonoid and polyphenol also can inhibit the melanogenesis process. ${ }^{13}$ Flavonoids are natural sunscreens to prevent skin damage from free radicals and effective phenolic substances to inhibit the formation of melanin. ${ }^{14}$

The antioxidant assay can be performed using stable free radical diphenylpicrylhydrazyl (DPPH) which can estimate the antioxidant activity of food or natural material..$^{15}$ The results of in vitro experiments have indicated that PPE hadlower DPPH scavenging activity compared to PTE $\left(\mathrm{IC}_{50}=84.09 \pm 4.87 ; 98.30 \pm 1.30 \mu \mathrm{g} / \mathrm{mL}\right)$ ( $p \leq 0.05)$. According to the results, it suggested that compounds in P. erosus had an antioxidant activities. Rusmarilin et al. ${ }^{16}$ study showed that P. erosus had strong antioxidant activity because $\mathrm{IC}_{50}$ value was less than $50 \mathrm{ppm}$ (39.72-11.99 $\mathrm{mg} / \mathrm{L}$ ). Another study suggested that P. erosus extract had antioxidant and inhibitory effect on melanin accumulation in B16F10 cells. ${ }^{17}$ P. erosus 
had flavonoids that exhibit various biological activities, including antioxidative and free radical scavenging activities. ${ }^{18}$ Pineros-Hernadez et al. ${ }^{19}$ have reported that polyphenols compound show strongly correlated with antioxidant activity, more higher level of polyphenols in plant and thereby had greater antioxidant activity. The results of the study showed that the higher the concentration of PPE and PTE also show the higher DPPH scavenging activity. This result in line with Lee et al. ${ }^{17}$ performing that $P$. erosus water and 70\% ethanol extracts had DPPH and ABTS scavenging activity which increased in a dose-dependent manner between 200 and 4000 $\mu \mathrm{g} / \mathrm{mL}$.

Tyrosinaseenzymecatalyzesthehydroxylation of L-tyrosine (mohophenol activity) and the oxidation of L-DOPA (diphenolase activity) to $o$-quinone, which induced the production of melanin pigment. ${ }^{1}$ In the present study, PPE had a higher inhibitory activity of tyrosinase compared to PTE with $\mathrm{IC}_{50}$ value $97.05 \mu \mathrm{g} / \mathrm{mL}(\mathrm{p} \leq 0.05)$. This result in line with Lukitaningsih et al..$^{20}$ study that PPE can suppress melanogenesis by inhibiting tyrosinase activity. Bioactive compounds of $P$. erosus can be used to decrease melanin production and can supress tyrosinase activity. ${ }^{20}$ $P$. erosus had active compounds as antioxidant and skin whitening activities such as daidzein, daidzin, genistin, (8,9)-furanyl-pterocarpan3-ol, 4-(2-(furane-2-yl)ethyl)-2-methyl-2,5dihydro-furane-3-carbaldehyde and 2-butoxy2,5-bis(hydroxymethyl)-tetrahydrofurane-3,4diol. ${ }^{20} P$. erosus compounds may have phenol or diphenol group which can form a chelate complex with copper $\left(\mathrm{Cu}^{2+}\right.$ ions). ${ }^{8}$ PTE may have a high amount of daidzein-7-O-ß-glucopyranose compared to PPE causing a lower inhibitory activity. ${ }^{8}$ Daidzein-7-0-ß-glucopyranose had only one phenol group because the other phenol groups bond to a glucose molecule which formed a weak complex resulting in lower inhibitory activity. ${ }^{8}$

Besides, DPPH scavenging activity and tyrosinase inhibition of PPE are higher than PTE that presumably due to the combination of activities between compounds and secondary metabolites contained therein. Therefore, $P$. erosus evidently which had the potential to be further natural source for antioxidant and antiaging therapy and can be used as skinwhitening agents in cosmetics.In summary, PTE effective to prevent skin aging, possibly through the antioxidant activity.

\section{References}

1. Zaidi KU, Ali AS, Ali SA, Naaz I. Microbial tyrosinases: promising enzymes for pharmaceutical, food bioprocessing, and environmental industry. Biochem Res Int. 2014;2014:1-16.

2. Setyawati A, Yamauchi K, Mitsunaga $T$. Potential of medicinal plants extractives as anti-melanogenesis ingredients. Rev Agric Sci. 2018;6(2018):46-60.

3. Wang $\mathrm{K}-\mathrm{H}$, Lin R-D, Hsu F-L, Huang $\mathrm{YH}$, Chang HC, Huang CY, et al. Cosmetic applications of selected traditional chinese herbal medicines. J Ethnopharmacol. 2006;106(3):353-9.

4. Altaei T. The treatment of malesma by silymarin cream. BMC Dermatol. 2012;12(1):1-6.

5. Unver N, Paul FP, Horster S, Wenck H, Stab F, Blatt T, et al. Alterations in the epidermaldermal melanin axis and factor XIIIa melanophages in senile lentigo and ageing skin. Br J Dermatol. 2006;155(1):119-28.

6. Noman ASM, Hoque MA, Haque MM, Pervin F, Karim MR. Nutritional and anti-nutritional components in Pachyrhizus erosus L. tuber. Food Chem. 2007;102(4):1112-8.

7. Pradeepika C, Selvakumar R, Krishnakumar T, Nabi SU, Sajeev MS. Pharmacology and phytochemistry of underexploited tuber crops: a review. J PharmacognPhytochem. 2018;7(5):1007-19.

8. Lukitaningsih E, Holzgrabe U. Bioactive compounds in bengkoang (Pachyrhizuserosus) as antioxidant and tyrosinase inhibiting agents. Indones J Pharm. 2014;25(2):68-75.

9. Widowati W, Janeva WB, Nadya S, Amalia A, Arumwardana S, Kusuma HSW, et al. 2018. Antioxidant and antiaging activities of Jasminum sambac extract and its compounds. J Rep Pharma Sci. 2018;7(3):270-85.

10. Tarigan JB.r, Zuhra CF, Sihotang DH. Skrining fitokimia tumbuhan yang digunakan oleh pedagang jamu gendong untuk merawat kulit wajah di kecamatan Medan Baru. J Biol Sumatera. 2008;3(1):1-6.

11. Sandler JA. The phytochemical extraction and analysis of new flavonoids and saponins from the genus Silphium [dissertation]. Austin: The University of Texas; 2005.

12. Cherian E, Sudheesh NP, Janardhanan KK, Patani G. Free radical scavenging and mitochondrial antioxidant activities of reishi- 
Ganoderma lucidum. J Basic Clin Physiol Pharmacol. 2011;20(2011):289-308.

13. Zhu W, Gao J. The use of botanical extracts as topical skin-lightening agents for the improvement of skin pigmentation disorders. J Investig Dermatol Symp Proc. 2008;13(1):20-24.

14. Chatatikun M, Chiabchalard A. Thai plants with high antioxidant levels, free radical scavenging activity, anti-tyrosinase and anti-collagenase activity. BMC Complement Altern Med. 2017;17(1):487.

15. Molyneux P. The use of the stable free radical Diphenylpicrylhydrazyl (DPPH) for estimating antioxidant activity. Songklanakarin J Sci Technol. 2004;26(2):211-9.

16. Rusmarilin H, Andayani RY. Soy-yamgurt probiotic drink as a natural potential of antioxidant. IOP Conf Ser Earth Environ Sci. 2018;122(1):012087.

17. Lee AR, Lee SA, Ju HJ, Noh JS, Roh SS, Kim
GN. Evaluation of nutri-cosmetical function of Jicama (Pachyrhizus erosus) extracts in B16F10 cells. Korean Society Food Sci Nutr. 2016;2016:455.

18. Okawa M, Kinjo J, Nohara T, Ono M. DPPH (1, 1-diphenyl-2-picrylhydrazyl) radical scavenging activity of flavonoids obtained from some medicinal plants. Biol Pharm Bull. 2001;24(10):1202-5.

19. Pineros-Hernandez D, Medina-Jaramillo C, López-Córdoba A, Goyanes S. Edible cassava starch films carrying rosemary antioxidant extracts for potential use as active food packaging. Food Hydrocoll. 2017;63(2017):488-95.

20. Lukitaningsih E, Mustikawaty AA, Sulistyo B, Sudarmanto A. Homology modeling and molecular docking of active compounds from bengkoang (Pachyrrhizus erosus) as tyrosinase inhibitor in homo sapien. J Ilmu Farm Indones. 2013;12(1):132-7. 